\title{
Childbirth in Teenagers at the Centre Hospitalier Universitaire Communautaire de Bangui
}

\author{
N. R. Ngbale*, A. Koirokpi, G. R. D. L. Kogboma-Wongo, C. Gaunefet, S. Ouapou, A. Touanga, \\ G. D. Kossa Ko Ouakoua, S. Matoulou-M'bala, A. Sepou
}

Obstetrics Gynecology Department, Centre Hospitalier Universitaire Communautaire de Bangui, Bangui, Sango

Email: ^ngbaler@yahoo.fr

How to cite this paper: Ngbale, N.R., Koirokpi, A., Kogboma-Wongo, G.R.D.L., Gaunefet, C., Ouapou, S., Touanga, A., Kossa Ko Ouakoua, G.D., Matoulou-M'bala, S. and Sepou, A. (2020) Childbirth in Teenagers at the Centre Hospitalier Universitaire Communautaire de Bangui. Open Journal of Obstetrics and Gynecology, 10, 1141-1146. https://doi.org/10.4236/ojog.2020.1080107

Received: August 8, 2020

Accepted: August 24, 2020

Published: August 27, 2020

Copyright $\odot 2020$ by author(s) and Scientific Research Publishing Inc. This work is licensed under the Creative Commons Attribution International License (CC BY 4.0).

http://creativecommons.org/licenses/by/4.0/

\begin{abstract}
Introduction: The teenager is the one whose chronological age is between 10 and 19 years according to the World Health Organization. Pregnancy during teenage age, whether desired or not, presents serious obstetric risks. The purpose of this study was to assess risk factors associated with childbirth in teenagers. Patients and Methods: This was an analytical cross-sectional study (witness case) conducted over the period from April 1st to September 30th, 2019 (6 months) in the maternity ward of the Centre Hospitalier Universitaire. It was included in the study all the parturients who were presented according to the place where the pregnancy was monitored. Results: A total of 510 childbirths were recorded during the study period, we identified 157 childbirth aged under 20 (teenager), and 353 controls. The frequency of childbirth for teenage girls was $30.7 \%$. The average age of teenage girls was 15 years with extremes of 13 19 years old. Risk factors were represented by preeclampsia, episiotomy. The low birth weight and premature birth are the most significant fetal morbidity. Conclusion: The pregnancy in teenagers is a public health issue.
\end{abstract}

\section{Keywords}

Teenagers, Morbidity, Central Africa, Amenorrhea Week (AW)

\section{Introduction}

The teenager is the one whose chronological age is between 10 and 19 years old according to the World Organization Health (WHO) [1]. In 2012, the WHO [2] estimated that almost 16 millions of teenage girls whose ages are from 15 to 19 years old and 2 millions of teenage girls under the age of 15 give birth every year in the world. The global teenage birth rate declined from 60 per 1000 in 1990 to 
48 per 1000 in 2007, with rates ranging from 5 per 1000 in East Asia to 121 per 1000 in Sub-Saharan Africa in 2007 [3].

Pregnancy during teenage age, whether desired or not, presents serious obstetric risks. Several studies have shown that the socio-economic situation of the parents, the educational level of the teenager as well as the one of the partners are risk factors for teenage pregnancy [3] [4] [5]. The teenager's vulnerability is linked to her physical aspect (pelvic immaturity) and the psychological aspect because pregnancy is difficult to accept at this age [5] [6]. In the Central African Republic (CAR), $20 \%$ to $30 \%$ of young girls have a baby before the age of 18 [7]. The purpose of this study was to assess the risk factors associated with childbirth in teenage girls in our maternity ward because the early pregnancy is frequent in our country.

\section{Patients and Methods}

This was an analytical cross-sectional study (witness case) conducted over the period from April 1st to September 30th, 2019 (6 months) in the maternity ward of the Centre Hospitalier Universitaire Communautaire. The study population consisted of parturients who delivered during the study period. The sample's size is consisted of all of the parturients who come to give birth during the study period.

They were included in the study all parturients who presented regardless of the place of pregnancy follow-up, whose pregnancy age was greater than or equal to 22 amenorrhea weeks. The pregnancy was mono-fetal and she voluntarily agreed to submit to the study requirements. These women were divided into two groups, according to their age: a group comprising parturients under the age of 20 (teenage girls) and a second group bringing together parturients aged 20 and over (Witnesses). The following parameters were collected: age of the parturient, age of pregnancy, age of first sexual intercourse, pregnancy desired or not, parity, abnormalities during labor, route of delivery, condition of the mother and the newborn.

We collected the data using a pre-designed questionnaire. The analysis was carried out on the SPSS12, EPI-INFOversion2011. The results were considered statistically significant from the $\mathrm{P}<0.05$ threshold.

\section{Results}

A total of 510 childbirths were recorded during the study period, we identified 157 childbirth aged less than 20 years (adolescent), and 353 witnesses. The frequency of childbirth for teenage girls was $30.7 \%$. The average age of adolescent girls was 15 with the extremes of 13 - 19. The average for the first sexual intercourse was 14 years old. $80.2 \%$ of teenage girls were first-time mothers. The pauciparous were the most found in witnesses $32.5 \%$. The big multiparous represented $9.8 \%$ of witnesses (Table 1 ). The frequency of preterm birth was $14 \%$ in teenage girls (Table 2 ). 
Table 1. Distribution of teenagers and witnesses according to the parity.

\begin{tabular}{cccc}
\hline Parity & Teenagers & Witnesses & \multirow{2}{*}{ Total (\%) } \\
\cline { 2 - 3 } & Number (\%) & Number (\%) & \\
\hline Primiparous & $140(80.2)$ & $106(30.2)$ & $246(48.2)$ \\
Pauciparous & $17(19.8)$ & $115(32.5)$ & $132(25.8)$ \\
Multiparous & $0(0.00)$ & $97(27.5)$ & $\mathbf{9 7}(19)$ \\
Big multiparous & $0(0.0)$ & $35(9.8)$ & $\mathbf{3 5 ( 7 )}$ \\
Total & $157(100)$ & $353(100)$ & $\mathbf{5 1 0 ( 1 0 0 )}$ \\
\hline
\end{tabular}

Table 2. Distribution of teenagers and witnesses according to the term of the pregnancy.

\begin{tabular}{cccc}
\hline \multirow{2}{*}{ Gestational Age } & Teenagers & Witnesses & \multirow{2}{*}{ Total } \\
\cline { 2 - 3 } & Number & Number & \\
\hline 22 to 36 AW & 22 & 15 & 37 \\
37 to $41 \mathrm{AW}$ & 135 & 338 & 473 \\
Total & 157 & 353 & 510 \\
\hline
\end{tabular}

Statistically significant associations were found between teenage age and the onset of preeclampsia $(\mathrm{p}<0.03)$, preterm birth $(\mathrm{p}<0.001)$, delivery after an episiotomy ( $\mathrm{p}<0.001$ ), and complications of postpartum $(\mathrm{p}<0.001)$ (Table 3$)$. Newborns of low weight were more found among teenagers with a statistically significant difference $(\mathrm{p}<0.001)$. Perinatal asphyxia and perinatal death were not a risk factor of childbirth in teenagers. The evacuation of the newborn in the neonatology department was found in the 2 groups (teenagers and witnesses) without a statistically significant difference (Table 4).

\section{Discussion}

We have realized a study in the Hospital that cannot be generalized in our Country. This is our study's limit. The frequency of teenage deliveries was $30.7 \%$. This result is almost identical to that of other authors [4] [7]. On the other hand, it is clearly higher than that of Adama who in his study carried out in Mali in 2015 found a frequency of $13.31 \%$ [8]. This difference between the observed frequencies could be explained by poverty, the low level of education and the precocity of sexual activity as in the study by Prosper Kakudji Luhete [9].

The average age of teenage girls was 15 years old. This average age was less than that found by Sépou (17.8) [7]. On the other hand, a study carried out by ILOKI in CONGO found the average age of teenage mothers at 14 years [10]. The average age is very low, is also probably due to poverty. The majority of teenage mothers were first-time mothers. This is explained by the fact that the CAR is among the countries where the literacy rate of young girls is low, and early marriages are frequent [7]. This result is similar to that found in Mali in 2015 by Adama reporting the proportion of first-time mothers at $82.4 \%$ [8]. The 
Table 3. Distribution of teenagers and witnesses according to the occurrence of maternal complications.

\begin{tabular}{|c|c|c|c|c|c|}
\hline & $\begin{array}{c}\text { yes } \\
\text { Number }\end{array}$ & $\begin{array}{c}\text { No } \\
\text { Number }\end{array}$ & $\mathrm{X}^{2}$ & RR (IC95\%) & $\mathbf{P}$ \\
\hline \multicolumn{6}{|c|}{ Eclampsia } \\
\hline Teenagers & 10 & 147 & 4.42 & $2.4[1.03-6.02]$ & $<0.001$ \\
\hline Witnesses & 9 & 344 & & & \\
\hline \multicolumn{6}{|c|}{ Premature Birth } \\
\hline Teenagers & 22 & 135 & 15.39 & $3.2[1.75-6.18]$ & $<0.001$ \\
\hline Witnesses & 15 & 338 & & & \\
\hline \multicolumn{6}{|c|}{ Caesarean } \\
\hline Teenagers & 12 & 145 & 1.00 & $0.8[0.39-1.36]$ & 0.31 \\
\hline Witnesses & 37 & 316 & & & \\
\hline \multicolumn{6}{|c|}{ Episiotomy } \\
\hline Teenagers & 110 & 47 & 93.20 & $2.8[2.28-3.46]$ & $<0.001$ \\
\hline Witnesses & 88 & 265 & & & \\
\hline \multicolumn{6}{|c|}{ Post-partum Complications } \\
\hline Teenagers & 10 & 147 & 15.92 & $11,2[2.49-50.71]$ & $<0.001$ \\
\hline Witnesses & 2 & 351 & & & \\
\hline
\end{tabular}

Table 4. Distribution of teenagers and witnesses according to the occurrence of neonatal complications.

\begin{tabular}{|c|c|c|c|c|c|}
\hline & $\begin{array}{c}\text { yes } \\
\text { Number }\end{array}$ & $\begin{array}{c}\text { No } \\
\text { Number }\end{array}$ & $\mathrm{X}^{2}$ & RR (IC95\%) & $\mathrm{p}$ \\
\hline \multicolumn{6}{|c|}{ Perinatal asphyxia } \\
\hline teenagers & 21 & 136 & 0.43 & $1.18[0.72-1.93]$ & 0.51 \\
\hline witnesses & 40 & 313 & & & \\
\hline \multicolumn{6}{|c|}{ Low birth weight } \\
\hline Teenagers & 18 & 139 & 8.3 & $2.5[1.32-4.82]$ & $<0.001$ \\
\hline Witnesses & 16 & 337 & & & \\
\hline \multicolumn{6}{|c|}{ Perinatal death } \\
\hline Teenagers & 1 & 156 & 0.90 & $0.37[0.04-3.08]$ & 0.34 \\
\hline Witnesses & 6 & 347 & & & \\
\hline \multicolumn{6}{|c|}{ Reference to neonatology } \\
\hline Teenagers & 10 & 147 & 0.09 & $1.12[0.53-2.34]$ & 0.75 \\
\hline Witnesses & 20 & 333 & & & \\
\hline
\end{tabular}

first sexual intercourse was at age 14 in $73 \%$ of adolescent girls. Sepou had already made this observation [7].

Episiotomy was performed in 110 childbirths, i.e. 70\% (Table 3) in the tee- 
nager group against $88 \%$ or $24.9 \%$ in the control group, with a statistically significant difference $(\mathrm{p}<0.001)$, Yattasaye in 1998 in Mali had found $57 \%$ and Treffers had found 62.7\% [6] [11]. The lack of control over the pain of childbirth would be at the origin of the episiotomy to protect the perineum. Preeclampsia was also found in predominantly adolescent girls ( $\mathrm{p}<0.001)$. Our results confirm the hypothesis that there is an association between young age and the onset of maternal complications [3] [12] [13] [14] [15]. According to several authors; teenage pregnancy, primiparity, celibacy, low socioeconomic status, constitute risk factors for the prognosis of childbirth (prematurity, low birth weight and intrauterine growth retardation) [5] [14] [15]. Low birth weight (Table 4) was more found in adolescent girls, $11.46 \%$, against $4.53 \%$ of controls with a difference being statistically significant $(\mathrm{p}<0.001)$. This rate is higher than that found by Adama 2.3\% [8] Diallo in Mali had found a similar rate of $11.8 \%$ [16]. The physical immaturity of the uterus (still hypoplastic) is often implicated in the birth of a premature baby and even that of a low birth weight. In addition to this physical immaturity, some authors blame the diet of teenage girls, which is generally more problematic than that of adults, by its poverty, and by its dietary habits. Teenage pregnancy generates specific nutritional and dietary needs, different from those of adult women's pregnancy, because the teenage body has not yet reached maturity, and continues to grow; hence the needs of pregnancy are added to those of growth [17] [18] [19].

\section{Conclusion}

This study has allowed us to observe that the evolution of pregnancy and childbirth in teenagers is marked by great morbidity. In view of our results, special attention should be paid to teenagers with regard to the quality of obstetrical and neonatal care provided in our hospitals. Pregnancy in teenagers is a real public health problem.

\section{Conflicts of Interest}

The authors declare no conflicts of interest regarding the publication of this paper.

\section{References}

[1] Organisation mondiale de la santé (2012) Mariage précoce, grossesse chez les adolescentes et les jeunes femmes. $65^{\mathrm{em}}$ assemblée mondiale de la santé. Point13.4 de l'ordre du jour.

[2] Organisation Mondiale de la Santé (2013) La grossesse chez les adolescentes. Aide-mémoire $\mathrm{n}^{\circ} 364$.

[3] Organisation mondiale de la santé (2012) Directives sur la prévention de la grossesse précoce et les résultats médiocres en matière de reproduction chez les adolescentes dans les pays en voie de développement.

[4] Ngbale, R.N., Diemer, S.C., Komangoya-Nzonzo, A.D., Tchombi, H., Koiropki, A., Olaoluwa, N., Goddot-Nangouma, M.J.C., Gaunefet, C.E., Songo-Kette, T. and 
Sépou, A. (2014) Facteurs de risque d'accouchement à terme de nouveau-nés de petit poids de naissance dans le service de Gynécologie-Obstétrique à l'Hôpital Communautaire de Bangui. Médecine d Afrique Noire, 61, 313-318.

[5] Poussoumandji, M. (2003) Grossesse chez les adolescentes dans la ville de Bouar. Thèse de médecine, Université de Bangui, $\mathrm{N}^{\circ} 45,85$.

[6] Yattassaye, A. (1998) L'accouchement de l'adolescente à la maternité de l'hôpital Gabriel Touré. Thèse de médecine, Université de Bamako, $\mathrm{N}^{\circ} 23,94$.

[7] Sépou, A., Yanza, M.C., Domandé-Modanga, Z. and Nguembi, E. (2002) Paramètres sexuels chez les femmes Centrafricaines en milieu urbain. Médecine d Afrique Noire, 49, 87-91.

[8] Adama, D. (2015) Grossesse et Accouchement chez l'adolescente au centre de sante de référence de la commune II du district de Bamako. Thèse de doctorat en médecine, Université Bamako, No. 238, 87 p.

[9] Kakudji Luhete, P., Mukuku, O., Mwembo-Tambwe, A., Kalenga-Muenze, P. and Kayamba, A. (2017) Etude du pronostic maternel et périnatal au cours de l'accouchement chez l'adolescente à Lubumbashi, République Démocratique du Congo. The Pan African Medical Journal, 26, 182. https://doi.org/10.11604/pamj.2017.26.182.9479

[10] Iloki, L.H., Koubaka, R., Itoua, C. and Mbemba Moutounou, G.M. (2004) Grossesse et accouchement chez l'adolescente au Congo: À propos de 276 cas au CHU de Brazzaville. Journal de Gynécologie Obstétrique et Biologie de la Reproduction, 33, 37-42. https://doi.org/10.1016/S0368-2315(04)96310-7

[11] Treffers, P.E., Olukoya, A.A., Ferguson, B.J. and Liljestrand, J. (2001) Soins pour la grossesse et l'accouchement de l'adolescente. International Journal of Gynecology \& Obstetrics, 75, 111-121. https://doi.org/10.1016/S0020-7292(01)00368-X

[12] Traore, B., Thera, T., Kokaina, C., Beye, S.A., Mounkoro, N., Teguete, I., Traore, M. and Dolo, A. (2010) Accouchement chez les adolescentes à la maternité du Centre Hospitalier Régional de Ségou au Mali: Pronostic obstétrical et néonatal. Médecine d Afrique Noire, 57, 449-454.

[13] Collège national des gynécologues et obstétriciens francais (2003) Extrait des mises à jour en gynécologie médicale.

[14] Souleymane, D. (2012) Accouchement chez l'adolescente au centre de santé de référence de Dioila. These de doctorat en médecine, Université de Bamako, $\mathrm{N}^{\circ} 56$, 94.

[15] Organisation Mondiale de la Santé (1995) Sante et développement des adolescentes. La clé de l'avenir. HO/ADH/94.3Rev1. Genève.

[16] Diallo, D. (1995) L'accouchement chez les adolescentes en milieu périurbain Thèse Méd. Bamako, $\mathrm{N}^{\circ} 48$.

[17] Lansac Lecompte, P. (1989) Gynécologie pour le praticien. $3^{\text {eme }}$ Edition, Simep, Paris, 512 .

[18] Ndiaye, O., Diallo, D., Ba, M.G., Diagne, I., Moreau, J.C., Diadhiou, F. and Kuakivi, N. (2001) Facteurs de risque maternels et petit poids du nouveau-né chez des adolescentes sénégalaises: L'exemple d'un centre hospitalier de Dakar. Cahiers Santé, 11, 241-244.

[19] Montgomery, S.K. (2003) Improving Nutrition in Pregnant Adolescents: Recommendations for Clinical Practitioners. The Journal of Perinatal Education, 12, 22-30. https://doi.org/10.1891/1058-1243.12.2.22 